\title{
THERAPEUTIC EFFICACY OF CHITOSAN NANOPARTICLES AND ALBENDAZOLE IN INTESTINAL MURINE TRICHINELLOSIS
}

\section{By}

\author{
NASHAAT E. NASSEF ${ }^{1}$, ISMAIL M. MOHARM ${ }^{1}$, AMANY F. ATIA ${ }^{1}$, REHAM \\ M. BRAKAT ${ }^{1}$, NOHA M. ABOU HUSSIEN ${ }^{1 *}$ AND ASMAA S. MOHAMED ${ }^{2}$ \\ Departments of Medical Parasitolog ${ }^{1}$ and Pathology ${ }^{2}$, Faculty of Medicine, \\ Menoufia University, Egypt ( ${ }^{\star}$ Correspondence:dr_nohaabohussein@yahoo.com)
}

\begin{abstract}
Most of the drugs used for the treatment of trichinellosis showed a limited bioavailability and a high degree of resistance. Therefore, there is an urgent need to develop new agents to improve the bioavailability of these drugs. This work assessed the use Chitosan $(\mathrm{CH})$ nanoparticles singly or combined with albendazole (ABZ) for the treatment of experimental trichinellosis. Fifty male albino mice were used. They were divided into six experimental groups. Chitosan nanoparticles were used orally at a dose of $100 \mathrm{mg} / \mathrm{kg} /$ day starting from $3^{\text {rd }}$ dpi for three successive days for the treatment of the intestinal phase of infection either alone or loaded with full dose or half dose of ABZ. Results showed significant reduction in all treated groups with the highest reduction rate of adult $99.1 \%$, improvement of the intestinal histopathological changes and a significant decrease in iNOS expression of the intestinal tissue were observed in groups treated by $\mathrm{CH}$ loaded with full dose of $\mathrm{ABZ}$ compared to control group
\end{abstract}

Key words: Trichinella spiralis, Albendazole, Chitosan Nanoparticles, Nitric oxide, SEM.

\section{Introduction}

Trichinellosis is a foodborne zoonotic parasite caused by Trichinella spiralis, which has a wide range of hosts including man (Ashour and Elbakary, 2011). It is widely distributed all over the world in most climates except for deserts with a burden of approximately 10,000 people per year and $0.2 \%$ mortality rate (Garcia et al, 2014). Humans acquire the infection by ingesting raw or insufficiently cooked meat of pigs or other animals containing Trichinella larvae. Following the ingestion of infected meat, Trichinella larvae are released from their capsules to invade the epithelial cells of the upper part of the small intestine and mature into adult worms. In 2-3 weeks, the fertilized females produce 1500 newborn larvae that migrate via the blood and lymphatic systems to invade and encapsulate in the skeletal muscles (Saad et al, 2016). Within the skeletal muscle, the Trichinella larvae induced the myocyte to transform into a new cell type called nurse cell, which maintains the life of the larvae for months to years (Despommier, 2009).

The life cycle of T. spiralis consists of two phases; enteral and muscular (Abou Rayia et $a l, 2017)$. The enteral phase is manifested by abdominal symptoms and gastroenteritis with diarrhea and abdominal pain (Wilson $e t$ $a l, 2015)$. It is usually diagnosed as acute food poisoning ( $\mathrm{Yu}$ and $\mathrm{Qi}, 2015$ ), while, the muscular phase is manifested by periorbital edema, myalgia and muscle weakness (Gottstein et al, 2009). Low-intensity of infection can remain asymptomatic but parasite burdens greater than a few hundred larvae can initially cause gastroenteritis with diarrhea and abdominal pain approximately two days post infection (p.i.) (Gottstein et al, 2009).The administration of efficacious anthelmintic drugs at the stage of intestinal invasion is remarkably important to obtain a better outcome. Though anthelminthics such as mebendazole and ABZ are commonly used to treat it but none of these drugs are fully effective against the encysted or newborn larvae of $T$. spiralis have a high degree of resistance and a weak activity against encapsulated larvae (Garcia et al, 2014). Also, it was poorly water soluble and highly lipophilic drug and consequently, it can exhibit unfavorable bioavailability after oral administration, leading to variable degree of oral absorption (Piccirilli et al, 2014). 
Nanoparticles have been used widely in previous studies as vehicles to deliver drugs or vaccines, to improve their therapeutic efficacy (Jiang et al, 2013; Gaafar et al, 2014). Chitosan $(\mathrm{CH})$ is a natural polysaccharide produced by deacetylation of chitin (AbdelLatif et al, 2017). The chitosan has antiinflammatory and antimicrobial activities due to its role in stimulating cellular, humoral immune response, strong inducer for mixed Th1/2 responses and for type I interferon (Neimert-Andersson et al, 2011; Xia et $a l, 2015)$. It has several properties, a) nontoxic, b) with various molecular weights, c) ability to form complexes with DNA as it effectively protects DNA from degradation, d) ability to enhance the penetration of large molecules across the mucosal surface, e) antibacterial and f) capability to be taken up by the payer's patches (Ali and Ahmed, 2018). Ghaly et al. (2019) found that crustacean derive chitosan have anticancer activity by induced cell toxicity that was cell type and concentrations dependent. Also, cell cycle, cell arrest profile was accompanied with the up and down regulation of the pro-apoptotic and the anti-apoptotic gene

The aim of the present study was to assess the use of chitosan nanoparticles alone or loaded with albendazole full and half dose in the treatment of mice experimentally infected with $T$. spiralis during the intestinal phase of the parasite cycle.

\section{Materials and Methods}

A total of 50 laboratory-bred free parasites, Swiss Albino mice weighing 18-20 g each, were used. Experimental animals were obtained from the animal house of Theodore Bilharz Research Institute, Giza, Egypt. Mice were fed on a standard pellet diet and water. The isolate of $T$. spiralis used was originally obtained from infected pork from Cairo abattoir and maintained in the laboratory of Medical Parasitology Department, Tanta Faculty of Medicine by consecutive passages in rats and mice. Trichinella isolate used was genotyped as $T$. spiralis by the European Union Reference Laboratory for Par- asites, Superior Institute of Health, Rome, Italy. They maintained in accordance with the institutional and national guide lines and were kept in the animal house exposed to 12 hours light / 12 hours dark and fed on standard diet and tap water. Stool examination was done prior to study to be sure that mice were free from any intestinal parasitic infection. Mice were orally infected with $200 \mathrm{~T}$. spiralis larvae/mouse (Dunn and Wright, 1985) and maintained in accordance with the institutional and national guidelines.

Drug administration: Albendazole drug was purchased as Alzental (Epico) from the pharmacy. One tablet (100mg) was dissolved in $50 \mathrm{ml}$ distilled water and given orally in a dose of $50 \mathrm{mg} / \mathrm{kg} /$ day (Attia et al, 2015). Chitosan nanoparticles: degree of deacetylation 93\%. From Sigma-Aldrich, USA, was used as a solution, given orally in a dose of $100 \mathrm{mg} / \mathrm{kg} /$ day. Chitosan nanoparticles loaded with either full dose or half dose of ABZ, was administered orally in a dose of $100 \mathrm{mg} / \mathrm{kg} /$ day (Akhtar et al., 2012).

Experimental design and sampling: The experimental animals were divided into six groups: GI (control negative) included 5 mice, GII (control positive) included 5 mice, GIII (infected treated by ABZ) contained 10 mice, GIV (infected treated by $\mathrm{CH}$ nanoparticles) contained 10 mice, GV (infected treated by $\mathrm{CH}$ nanoparticles loaded with full dose of ABZ) contained 10 mice and GVI (infected treated by $\mathrm{CH}$ nanoparticles loaded with half dose of ABZ) contained 10 mice. The drugs were given three days post infection in all groups for three consecutive days and mice were sacrificed on $6^{\text {th }}$ day post infection to evaluate the drugs action on the intestinal phase. Small intestines were dissected out, opened longitudinally, washed and one piece of the middle third of the ten mice were stored in $10 \%$ formalin for histopathological \& immunohistochemical studied. T. spiralis adults were counted, isolated and preserved in glutraldehyde solution for SEM study.

T. spiralis adult count in the intestine: The 
washed intestine was cut into small pieces 1 $\mathrm{cm}$ each and incubated at $37^{\circ} \mathrm{C}$ in a $250 \mathrm{ml}$ beaker containing $100 \mathrm{ml}$ of Hanks' balanced salt solution for $2 \mathrm{hrs}$ to allow the worms to migrate out of the tissue and collect in the container. The solution was pipetted and the intestine was washed several times with saline. All fluid was collected in tubes and centrifuged at $1500 \mathrm{rpm}$ for $5 \mathrm{~min}$. To count worms, the supernatant was decanted and the sediment reconstituted in 3-5 drops of saline and then examined drop by drop at a magnification of $\times 10$ (Issa et al, 1998).

Efficacy of treatment $(\%)=100 \mathrm{x}$ mean No. recovered in controls minus mean number recovered in treated mouse/ mean No. recovered in controls (Ashour et al, 2016).

Histopathological examination: For histopathological examination, intestinal specimens $(1 \mathrm{~cm}$ from the small intestine at the junction of the proximal $1 / 3$ and distal $2 / 3$ ) were taken from mice sacrificed on the $7^{\text {th }}$ dpi. These specimens were fixed in $10 \%$ formalin, dehydrated, cleared and then embedded in paraffin blocks. Formalin-fixed, paraffin-embedded sections ( $5 \mu \mathrm{m}$ thickness) were prepared and stained with hematoxylin and eosin (Nassef et al, 2010).

Immunohistochemical staining of iNOS: The iNOS protein was analyzed by immunehistochemical staining using avidin biotin immunoperoxidase complex technique (Ultravision Plus Detection System antipolyvalent HRP/DAB, ready to use; Thermo Scientific Corporation, USA). Immunohistochemistry was performed according to the manufacturing protocol. Tissue sections $(4-\mu \mathrm{m}$ thick) of the previously formalin-fixed, paraffin-embedded specimens were cut and mounted. The sections were de-paraffinised and rehydrated in graded alcohol and endogenous peroxidase was blocked by using 3\% hydrogen peroxide in methanol for $5 \mathrm{~min}$. For antigen retrieval, slides were immersed in a citrate buffer and put in the microwave for $8 \mathrm{~min}$. Samples were then incubated for 1 $\mathrm{hr}$ at room temperature with iNOS (rabbit polyclonal antibody; Thermo Scientific Cor- poration) at a dilution of 1:100. After secondary antibody application, slides were developed using 3-3'-diaminobenzidine chromogen and counterstained with hematoxylin. Negative control slides were made by omitting primary antibody. Sections from lung were stained as a positive control (Attia et al, 2015).

Evaluation of iNOS expression: iNOS immune stains were assessed microscopically in $10 \mathrm{HPF}$ (x400) in each section. Positive cells for iNOS showed brownish cytoplasmic staining semi-quantitatively scored based on the percentage of positive cells as follows: $0(0-9 \%),+1(10-49 \%$ positive cells), $+2(50-89 \%$ positive cells), +3 (>90\% positive cells). Staining intensity was graded as follows: 0 (no staining), +1 : weak, +2 : moderate and +3 : strong. The final scores were calculated by multiplying the quantity score with intensity score, divided by 3 , with a range from 0 to 9 . A score of 7-9 was considered a strong immunoreactivity $(+3)$; 46: moderate $(+2) ; 1-3$ : weak $(+1)$; and 0 : negative (Ravn et al, 1993; Lee et al, 2008).

SEM: Worms were directly pipetted into a fresh fixation solution of $2.5 \%$ glutaraldehyde $(\mathrm{w} / \mathrm{v})$ in $0.1 \mathrm{M}$ sodium cacodylate at $\mathrm{pH}$ 7.2 and left overnight at $3{ }^{\circ} \mathrm{C}$. Worms were washed in $0.1 \mathrm{M}$ sodiumcacodylate buffer at $\mathrm{pH} 7.2$ for $5 \mathrm{~min}$, post-fixed in a $2 \%(\mathrm{w} / \mathrm{v})$ osmiumtetroxide in sodium cacodylate buffer for $1 \mathrm{hr}$. The specimens were dehydrated in an alcohol series, dried using liquid carbon dioxide and mounted on stub. After sputter coating with gold, they were examined in Jeol SEM (Mitaka, Japan) after Bughdadi (2010).

Statistical analysis: Data collected were tabulated and analyzed by SPSS version 22.0 on IBM compatible computer. Quantitative values of the measured parameters were expressed as mean \pm standard deviation (SD). Mann-Whitney test and chi-square $\left(\chi^{2}\right)$ test were used. Difference was significant when $\mathrm{P}<0.05$, highly significant when $\mathrm{p}<0.01$ and not significant when $\mathrm{p}>0.05$. 


\section{Results}

The lowest mean adult count was in GV received chitosan nanoparticles loaded with albendazole $(1.8 \pm 1.03)$ and showed the most effective eradication of $T$. spiralis worms, with drug efficacy of $99.1 \%$ (Tab. 1).

Concerning the histopathological changes in the intestinal phase of the infection, examination of the infected control (GII) revealed severe inflammation, dense inflammatory infiltrate in lamina propria, edema, destruction of intestinal villi and ulceration. Marked improvement of inflammation was observed in group treated with $\mathrm{CH}$ nanoparticles loaded with full dose of ABZ (GV). Most of the infected mice that were treated with ABZ (GIII), showed moderate degree of inflammation, while $\mathrm{CH}$ treated group (GIV) showed severe inflammation.

The immunohistochemical expression of the iNOS in the intestinal sections of the infected control group revealed strong cytoplasmic staining $(+3)$ in the inflammatory cellular infiltrate within the villous core. The lowest intensity of iNOS expression $(80 \%)$ was noticed in group treated with $\mathrm{CH}$ nanoparticles loaded with full dose of ABZ (GV) with weak expression $(+1)$ and mild cytoplasmic staining in the inflammatory cellular infiltrate within the villous core and around the crypts. Most of the infected mice that were treated with ABZ (GIII), showed moderate degree of inflammation, while $\mathrm{CH}$ treated group (GIV) showed strong iNOS expression (+3). No significant difference was observed between groups received $\mathrm{CH}$ loaded with full dose of $\mathrm{ABZ}$ or $\mathrm{CH}$ loaded with half dose of ABZ either as regards histopathological or immunohistochemical changes in the intestine.

SEM examination of adult worms in infected untreated group showed normal morphology with preserved cuticle, characteristic transverse creases, ridges and annulations with normal appearance of the hypodermal gland openings (GII). While marked destruction of the adult worm's cuticle in all treated groups with more destruction in the subgroup treated by $\mathrm{CH}$ loaded with full dose of ALB (GVI). Cuticle showed areas with marked swellings, complete disappearance of the internal content, loss of the normal creases, ridges and annulations of the cuticle. Sloughing of some areas of the cuticle was observed in the group treated by chitosan nanoparticles (GIV).

The details were given in tables $(1,2 \& 3)$ and figure (a, b, c, d, e, f, g \& h).

Table 1: Comparison between control $(n=5)$ and treated $(n=10)$ regarding adult count $(N=10)$

\begin{tabular}{|c|c|c|c|c|c|}
\hline \multirow[b]{2}{*}{ Groups } & \multicolumn{2}{|c|}{ Adult count } & \multirow[b]{2}{*}{$\begin{array}{c}\text { Reduction } \\
\%\end{array}$} & \multirow{2}{*}{ Mann Whitney test } & \multirow[b]{2}{*}{$\begin{array}{l}P \text { value of } \\
\text { mean }\end{array}$} \\
\hline & $\mathrm{M} \pm \mathrm{SD}$ & Range & & & \\
\hline GI (Control -ve) & No & No & No & $\begin{array}{l}\text { II vs. III }=3.15 \\
\text { II vs. IV }=3.09\end{array}$ & $\begin{array}{l}\mathrm{P} 1=0.002 * \\
\mathrm{P} 2=0.002 *\end{array}$ \\
\hline GII (Control +ve) & $202.0 \pm 17.9$ & $170-210$ & $0 \%$ & $\begin{array}{l}\text { II vs. } V=3.16 \\
\text { II vs. VI }=3.26\end{array}$ & $\begin{array}{l}\mathrm{P} 3=0.002 * \\
\mathrm{P} 4=0.001 * *\end{array}$ \\
\hline GIII (TTT ABZ) & $19.8 \pm 5.6$ & $13-25$ & 90. & $\begin{array}{l}\text { III vs. IV }=3.79 \\
\text { III vs. V }=3.84\end{array}$ & $\begin{array}{l}\mathrm{P} 5<0.001 * * \\
\mathrm{P} 6<0.001 * *\end{array}$ \\
\hline Group IV(TTT CH) & $73.9 \pm 9.7$ & $62-89$ & $63.3 \%$ & $\begin{array}{c}\text { III vs. VI }=3.89 \\
\text { IV vs. V }=3.82\end{array}$ & $\begin{array}{l}\mathrm{P} 7<0.001 * * \\
\mathrm{P} 8<0.001 * *\end{array}$ \\
\hline GV (TTT CH + full ABZ) & $1.8 \pm 1.03$ & $1-4$ & $99.1 \%$ & $\begin{array}{l}\text { IV vs. VI }=3.87 \\
\text { V vs. VI }=1.84\end{array}$ & $\begin{array}{l}\mathrm{P} 9<0.001 * * \\
\mathrm{P} 10=0.07\end{array}$ \\
\hline GVI (TTT CH +half ABZ) & $2.5 \pm 0.97$ & $2-5$ & $98.8 \%$ & & \\
\hline
\end{tabular}


Table 2: Histopathological examination of intestinal tissues of control $(n=5)$ and treated $(n=10)$

\begin{tabular}{|c|c|c|c|c|c|}
\hline groups & Inflammation Degree & Inflamn & ry Intensity & $\chi^{2}$ test & \multirow{7}{*}{$\begin{array}{l}\quad \mathrm{P} \text { value } \\
\mathrm{P} 1=0.007 * \\
\mathrm{P} 2=0.002 * \\
\mathrm{P} 3=0.001 * * \\
\mathrm{P} 4=0.01 * \\
\mathrm{P} 5=0.002 * \\
\mathrm{P} 6=0.02 * \\
\mathrm{P} 7=0.68 \\
\mathrm{P} 8=0.005 * \\
\mathrm{P} 9=0.01 * \\
\mathrm{P} 10=0.02 * \\
\mathrm{P} 11=0.005 * \\
\mathrm{P} 12=0.01 * \\
\mathrm{P} 13=0.001 * * \\
\mathrm{P} 14=0.003 * \\
\mathrm{P} 15=0.34\end{array}$} \\
\hline GI (Control -ve) & 0 & $\begin{array}{c}\text { No. } \\
5\end{array}$ & $\begin{array}{l}\% \\
100 \\
\end{array}$ & \multirow{6}{*}{$\begin{array}{c}\text { I versus II }=10.0 \\
\text { I versus III }=15.0 \\
\text { I versus IV }=15.0 \\
\text { I versus } \mathrm{V}=8.57 \\
\text { I versus } \mathrm{VI}=15.0 \\
\text { II versus III }=7.40 \\
\text { II versus IV }=0.17 \\
\text { II versus } \mathrm{V}=12.75 \\
\text { II versus } \mathrm{VI}=8.40 \\
\text { III versus IV }=7.77 \\
\text { III versus V }=12.94 \\
\text { III versus } \mathrm{VI}=8.10 \\
\text { IV versus } \mathrm{V}=17.0 \\
\text { IV versus } \mathrm{VI}=11.70 \\
\mathrm{~V} \text { versus } \mathrm{VI}=3.33\end{array}$} & \\
\hline GII (Control +ve) & $\begin{array}{l}+2 \\
+3 \\
\end{array}$ & $\begin{array}{l}1 \\
4 \\
\end{array}$ & $\begin{array}{l}20.0 \\
80.0\end{array}$ & & \\
\hline $\begin{array}{l}\text { GIII (infected TTT } \\
\text { ABZ) }(n=10)\end{array}$ & $\begin{array}{l}+1 \\
+2 \\
+3 \\
\end{array}$ & $\begin{array}{l}1 \\
8 \\
1 \\
\end{array}$ & $\begin{array}{l}10.0 \\
80.0 \\
10.0\end{array}$ & & \\
\hline $\begin{array}{l}\text { GIV (infected } \\
\text { CHT }(\mathrm{n}=10)\end{array}$ & $\begin{array}{l}+2 \\
+3 \\
\end{array}$ & $\begin{array}{l}3 \\
7\end{array}$ & $\begin{array}{l}30.0 \\
70.0 \\
\end{array}$ & & \\
\hline $\begin{array}{l}\text { GV (infected } \\
\mathrm{CH}+\text { full ABZ) }\end{array}$ & $\begin{array}{c}0 \\
+1 \\
+2 \\
\end{array}$ & $\begin{array}{l}2 \\
7 \\
1 \\
\end{array}$ & $\begin{array}{l}20.0 \\
70.0 \\
10.0 \\
\end{array}$ & & \\
\hline $\begin{array}{l}\text { GVI (infected TTT } \\
\mathrm{CH}+\text { half } \mathrm{ABZ})\end{array}$ & $\begin{array}{l}+1 \\
+2 \\
+3 \\
\end{array}$ & $\begin{array}{l}7 \\
2 \\
1 \\
\end{array}$ & $\begin{array}{l}70.0 \\
20.0 \\
10.0\end{array}$ & & \\
\hline
\end{tabular}

Table 3: iNOS expressions in intestinal tissues of control $(n=5)$ and treated $(n=10)$

\begin{tabular}{|c|c|c|c|c|c|}
\hline Groups & iNOS intensity expression & iNOSc & ppression & \multirow{7}{*}{$\begin{array}{l}\chi \chi^{2} \text { test } \\
\text { I versus II }=10.0 \\
\text { I versus III }=15.0 \\
\text { I versus IV }=15.0 \\
\text { I versus } \mathrm{V}=8.57 \\
\text { I versus } \mathrm{VI}=15.0 \\
\text { II versus III }=7.40 \\
\text { II versus IV }=0.00 \\
\text { II versus } \mathrm{V}=15.0 \\
\text { II versus } \mathrm{VI}=11.63 \\
\text { III versus IV }=10.04 \\
\text { III versus } \mathrm{V}=16.44 \\
\text { III versus } \mathrm{VI}=7.77 \\
\text { IV versus } \mathrm{V}=20.0 \\
\text { IV versus } \mathrm{VI}=15.20 \\
\mathrm{~V} \text { versus } \mathrm{VI}=5.07\end{array}$} & \multirow{7}{*}{$\begin{array}{l}\mathrm{P} \text { value } \\
\mathrm{P} 1=0.007^{*} \\
\mathrm{P} 2=0.002^{*} \\
\mathrm{P} 3=0.001^{*} \\
\mathrm{P} 4=0.003^{*} \\
\mathrm{P} 5=0.001^{* *} \\
\mathrm{P} 6=0.02^{*} \\
\mathrm{P} 7=1.00 \\
\mathrm{P} 8=0.002^{*} \\
\mathrm{P} 9=0.003^{*} \\
\mathrm{P} 10=0.007^{*} \\
\mathrm{P} 11=0.001^{*} \\
\mathrm{P} 12=0.02^{*} \\
\mathrm{P} 13<0.001^{* *} \\
\mathrm{P} 14=0.001^{* *} \\
\mathrm{P} 15=0.08\end{array}$} \\
\hline GI (control -ve) $(n=5)$ & 0 & $\begin{array}{c}\text { No. } \\
5\end{array}$ & $\begin{array}{c}\% \\
100\end{array}$ & & \\
\hline GII (control +ve) $(n=5)$ & $\begin{array}{l}+2 \\
+3 \\
\end{array}$ & $\begin{array}{l}1 \\
4\end{array}$ & $\begin{array}{l}20.0 \\
80.0\end{array}$ & & \\
\hline $\begin{array}{l}\text { GIII (infected } \\
\text { ABZ) }(n=10)\end{array}$ & $\begin{array}{l}+1 \\
+2 \\
+3 \\
\end{array}$ & $\begin{array}{l}1 \\
8 \\
1 \\
\end{array}$ & $\begin{array}{l}10.0 \\
80.0 \\
10.0\end{array}$ & & \\
\hline $\begin{array}{l}\text { GIV (infected TTT CH) } \\
(\mathrm{n}=10)\end{array}$ & $\begin{array}{r}+2 \\
+3 \\
+\end{array}$ & $\begin{array}{l}2 \\
8 \\
\end{array}$ & $\begin{array}{l}20.0 \\
80.0\end{array}$ & & \\
\hline $\begin{array}{l}\text { GV (infected TTT } \mathrm{CH}+ \\
\text { full ABZ) }(\mathrm{n}=10)\end{array}$ & $\begin{array}{r}0 \\
+1 \\
\end{array}$ & $\begin{array}{l}2 \\
8 \\
\end{array}$ & $\begin{array}{l}20.0 \\
80.0\end{array}$ & & \\
\hline $\begin{array}{l}\text { GVI (infected TTT CH } \\
+ \text { half ABZ) }(\mathrm{n}=10)\end{array}$ & $\begin{array}{l}+1 \\
+2\end{array}$ & $\begin{array}{l}7 \\
3\end{array}$ & $\begin{array}{l}70.0 \\
30.0\end{array}$ & & \\
\hline
\end{tabular}

\section{Discussion}

Albendazole is extensively used against intestinal parasites due to its extended spectrum activity and low cost (Priotti et al, 2017). But, its effectiveness influenced by several key factors, such as oral bioavailability, which mainly depends on the solubility, dosage of therapy and the host biotransformation as well as time of onset of treatment after infection (Virkel et al, 2002; Solana et $a l$, 2009). Therefore, this work aimed to assess the use of chitosan nanoparticles alone or loaded with albendazole full and half doses in the treatment of mice experimentally infected with trichinellosis during the intestinal of the parasite cycle.

The results agreed with Priotti et al. (2017) who indicated that the microcrystals made with chitosan appear to be the best options to optimize oral absorption of the active pharmaceutical ingredient. Also, Garcia et al. (2013) reported that microencapsulated formulations (based on chitosan particles with different concentrations), designed to improve albendazole dissolution rate in treating $T$. spiralis infected mice during the intestinal phase of the parasite cycle. The high therapeutic response observed was due to a better bioavailability of albendazole and improvement of the intestinal bioavailability of the drug in these formulations and improving the drug dissolution rate and consequently, its absorption by intestinal $T$. spiralis worms. It is well-known that the smaller the particle size, the larger the surface area and the faster the dissolution rate of drug particles (Priotti et al, 2017).

Chitosan results agreed with Hoseini $e t a l$. (2016) who reported that treatment with chitin and chitosan MPs induced a protective response in L. major-infected BALB/c mice, but lower than that obtained by Abdel-Latif 
et al. (2017), who reported reduction in both adult and egg count in mice infected with $H$. nana after treatment by chitosan particles (95\% for adult and $77 \%$ for eggs).

The present results disagreed with Gaafar et al. (2014), who did not report significant reduction in the parasite count in the infected group treated with chitosan nanoparticles compared to controls in the treatment of murine toxoplasmosis.

Histopathological changes correlated with previous studies (Shalaby et al, 2010; Abou Rayia et al, 2017). Control of inflammation reduced systemic cytokine release from activated immune cells that relieved systemic manifestations like fever, tissue edema and vasculitis (Kociecka, 2000). Besides, AbdelLatif et al. (2017) was against the present chitosan results. Where chitosan induced improvement in intestinal morphometric measurements and reversed alterations to nearly normal length and width as well as crypts in Hymenolepis nana infected mice.

Nitric oxide (NO) production during the intestinal phase of Trichinella showed a preventive effect against the parasite establishment (Kolodziej-Sobocinska et al, 2006). Also, NO was associated with the pathogenesis of enteropathy and smooth muscle hypermotility during $T$. spiralis infection, and inhibition of inducible nitric oxide synthase (iNOS) abolished intestinal hypermotility (Torrents et al, 2003;Othman et al, 2016).

The present results agreed iNOS expression in mice infected with $T$. spiralis (Zeromski et al, 2005; Yu et al, 2013; Attia et al. 2015). Also, many studies reported the stimulatory effect of ALB on enzymes involved in oxygen and nitrogen free radicalbased host defense (iNOS) in trichinellosis (Derda et al, 2003, Boczon et al, 2004; Zeromski et al, 2005), which explained iNOS expression in ALB treated groups. Also, the effects of chitosan on iNOS expression agreed with Peluso et al. (1994) and Li et al. agreed with Peluso et al. (1994) and Li et al. (2009); Porporatto et al. (2003) and Yu et al. (2004) who reported that the increased activity of iNOS and induced synthesis of NO in macrophages was influenced by chitosan. But, Abdel-Latif et al. (2017) reported that, the expression level of iNOS was decreased in the intestinal tissue by chitosan particles in mice experimentally infected with H. nana.

During the intestinal phase of $T$. spiralis, NO contributed to the intestinal pathology and prevented effect against the infection establishment (Boczon et al, 2004; Kolodziej-Sobocinska et al, 2006). Inhibition of the iNOS abolished intestinal hypermotility (Othman et al, 2016).

SEM results agreed with Abou Rayia et al. (2016) who found significant degeneration and destruction in adult teguments in mice infected with $T$. spiralis and treated with the artemisinin and mebendazole. Hammouda et al. (1992) found that changes in organisms shape were secondary to changes due to interference of drugs with DNA synthesis of parasite or interference with folic acid cycle. Also, Gaafar et al. (2014) reported disorganized conoid in SEM in the treatment of murine toxoplasmosis with chitosan and silver nanoparticles.

\section{Conclusion}

Chitosan nanoparticles loaded with ABZ proved a promising drug against adults of $T$. spiralis in experimentally infected mice.

\section{References}

Abdel-Latif, M, El-Shahawi, G, Aboelhadid, SM, Abdel-Tawab, H, 2017: Immunoprotective effect of chitosan particles on Hymenolepis nana-infected mice. Scand. J. Immunol. 86, 2:8390.

Abou Rayia, DM, Saad, AE, Ashour, DS, Oreiby, RM, 2017: Implication of artemisinin nematocidal activity on experimental trichinellosis: In vitro and in vivo studies. Parasitol. Int. 66, 2: 56-63.

Akhtar, F, Rizvi, MM, Kar, SK, 2012: Oral delivery of curcumin bound to chitosan nanoparticles cured Plasmodium yoelii infected mice. Biotechnol. Adv. 30, 1:310-20.

Ali, A, Ahmed, S, 2018: A review on chitosan and its nanocomposites in drug delivery. Int. J. Biol. Macromol. 109:273-86. 
Ashour, DS, Abou Rayia, DM, Saad, AE, ElBakary, RH, 2016: Nitazoxanide anthelminthic activity against the enteral and parenteral phases of trichinellosis in experimentally infected rats. Exp. Parasitol. 170:28-35.

Ashour, DS, Elbakary, RH, 2011: Pathogenesis of restricted movements in trichinellosis: an experimental study. Exp. Parasitol. 128:414-8.

Attia, RA, Mahmoud, AE, Farrag, HM, Makboul, R, Mohamed, ME, et al, 2015: Effect of myrrh and thyme on Trichinella spiralis enteral and parenteral phases width inducible nitric oxide expression in mice. Mem. Inst. Oswaldo Cruz 110, 8:1035-41.

Boczon, K, Wandurska-Nowak, E, Wierzbicki, A, Frydrychowicz, M, Moser-Lisewska, I, et al, 2004: mRNA expression and immunohistochemical localization of inducible nitric oxide synthase (NOS-2) in the muscular niche of Trichinella spiralis. Folia. Histochem. Cytobiol. 42:209-13.

Bughdadi, FA, 2010: Ultrastractural studies on the parasitic worm Trichinella spiralis. J. Taibah Univ. Sci. 1, 3:33-8.

Derda, M, Boczon, K, Wandurska-Nowak, E, Wojt, W, 2003: Changes in the activity of Sglutathione transferase in muscles and sera from mice infected with Trichinella spiralis after treatment with albendazole and levamisole. Parasit. Res. 89:509-12.

Despommier, DD, 2009: Trichinellida, Dioctophymatida and Enoplean Parasites, Ch.23. In: Foundations of Parasitology, $8^{\text {th }}$ ed. McGrawHill Co. Inc., New York.

Dunn, IJ, Wright, KA, 1985: Cell injury caused by Trichinella spiralis in the mucosal epithelium of B10A mice. J. Parasitol, 71, 6:757-66.

Gaafar, MR, Mady, RF, Diab, RG, Shalaby, TI, 2014: Chitosan and silver nanoparticles: promising anti-toxoplasma agents. Exp. Parasitol 143:30- 8 .

Garcia, A, Barrera, MG, Piccirilli, G, Vasconi, MD, Di Masso, RJ, 2013: Novel albendazole formulations given during the intestinal phase of Trichinella spiralis infection reduce effectively parasitic muscle burden in mice. Parasitol. Int. 62, 6:568-70.

Garcia, A, Leonardi, D, Vasconi, MD, Hinrichsen, LI, Lamas MC, 2014: Characterization of albendazole- randomly methylated- $\beta$ - cyclodextrin inclusion complex and in vivo evaluation of its anthelminthic activity in a murine model of trichinellosis. PLoS. One 9:113296.
Ghaly, CAF, Bakaar, A, Mohamed, AF, 2018: In vitro assessment of anticancer activity of shri$\mathrm{mp}$ derived chitosan and related apoptotic profile alteration. J. Egypt. Soc. Parasitol. 48, 2: 379-88 Gottstein, B, Pozio, E, Nockler, K, 2009: Epidemiology, diagnosis treatment and control of trichinellosis. Clin. Microbiol, 22:127-45.

Hammouda, NA, el-Gebali, WM, Razek, MK, 1992: Intestinal parasitic infection among sewage workers in Alexandria, Egypt. J. Soc. Parasitol. 22, 2:299-303.

Hoseini, MH, Moradi, M, Alimohammadian, MH, Shahgoli, VK, Darabi, H, et al, 2016: Immunotherapeutic effects of chitin in comparison with chitosan against Leishmania major infection. Parasitol. Int. 65, 2:99-104.

Issa, RM, El-Arousy, MH, Abd EI-Aal, AA, 1998: Albendazole: A study of its effect on experimental Trichinella spiralis infection in rats. Egypt. J. Med. Sci, 19:281-90.

Jiang, S, Hua, E, Liang, M, Liu, B, Xie, G, 2013: A novel immunosensor for detecting Toxoplasma gondii-specific IgM based on goldmag nanoparticles and grapheme sheets. Colloids Surf. B. Biointerface 101:481-6.

Kociecka, W, 2000: Trichinellosis: Human disease, diagnosis and treatment, Vet. Parasitol. 93: 365-83.

Kolodziej-Sobocinska, M, Dvoroznakova, E, Dziemian, E, 2006: Trichinella spiralis: macrophage activity and antibody response in chronic murine infection. Exp. Parasitol. 112, 1:52- 62.

Lee, LY, Chi-Ming, W, Wang, CC, Song, JY, Liang, Y, et al, 2008: Expression of matrix metalloproteinases MMP-2 and MMP-9 in gastric cancer and their relation to claudin-4 expression. Histol Histopathol. 23:515-21.

Li, HY, Yan, SM, Shi, BL, Guo, XY, 2009: Effect of chitosan on nitric oxide content and inducible nitric oxide synthase activity in serum and expression of inducible nitric oxide synthase mRNA in small intestine of broiler chickens. Asian-Aust. J. Anim. Sci. 22, 7:1048-53.

Nassef, NE, El-Sobky, MM, Afifi, AF, 2010: Worm and larval burden, histopathological and ultrastructural evaluation of $T$. spiralis vaccination using crude worms and/or larvae antigens: Experimental studies. PUJ. 3:27-38.

Neimert-Andersson, T, Hallgren, AC, Andersson, M, Langeback, J, Zettergren, L, et al, 2011: Improved immune responses in mice using the novel chitosan adjuvant Visco Gel, with a Haemophilus influenzae type b glycoconjugate 
vaccine. Vaccine, 29:8965-73.

Othman, AA, Abou-Rayia, DM, Ashour, DS, Saied, EM, Zineldeen, DH, et al, 2016: Atorvastatin and metformin administration modulates experimental Trichinella spiralis infection. Parasitol. Int. 65, 2:105-12.

Peluso, G, Petillo, O, Ranieri, M, Santin, M, Ambrosio, L, et al, 1994: Chitosan mediated stimulation of macrophage function. Biomaterials 15, 15:1215-20.

Piccirilli, GN, Garcia, A, Leonardi, D, Mamprin, ME, Bolmaro, RE, et al, 2014: Chitosan micro particles: Influence of the gelation process on the release profile and oral bioavailability of albendazole, a class II4 Drug. Dev. Compound. Ind. Pharm. 40, 11:1476-82

Porporatto, C, Bianco, ID, Riera, CM, Corres, SG, 2003: Chitosan induces different L-arginine metabolic pathways in resting and inflammatory macrophages. J. Biochem. Biophys. Res. Commun. 304, 2:266-72.

Priotti, J, Codina, AV, Leonardi, D, Vasconi, MD, Hinrichsen LI, et al, 2017: Albendazole microcrystal formulations based on chitosan and cellulose derivatives: physicochemical characterization and in vitro parasiticidal activity in Trichinella spiralis adult worms. AAPS. Pharm. Sci. Tech. 18, 4:947-56.

Ravn, V, Rasmussen, BB, Hojholt, L, 1993: Reproducibility of subjective immunohistochemical estrogen- and progesterone receptor determination in human endometrium. Pathol. Res. Pract. 189:1015-22.

Saad, AE, Ashour, DS, Abou Rayia, DM, Bedeer, AE, 2016: Carbonic anhydrase enzyme as a potential therapeutic target for experimental trichinellosis. Parasitol. Res, 115, 6:2331-39.

Shalaby, MA, Moghazy, FM, Shalaby, HA, Nasr SM, 2010: Effect of methanolic extract of Balanites aegyptiaca fruits on enteral and parenteral stages of Trichinella spiralis in rats. Parasitol. Res. 107:17-25.
Solana, H, Scarcella, S, Virkel, G, Ceriani, C, Rodriguez, J, et al, 2009: Albendazole enantiomeric metabolism and binding to cytosolic proteins in the liver fluke Fasciola hepatica. Vet. Res. Commun, 33, 2:163-73.

Torrents, D, Prats, N, Vergara, P, 2003: Inducible nitric oxide synthase inhibitors ameliorate hypermotility observed after $T$. spiralis infection in the rat. Dig. Dis. Sci. 48, 6:1035-49.

Virkel, G, Lifschitz, A, Pis, A, Lanusse, C, 2002: In vitro ruminal biotransformation of benzimidazole sulphoxide anthelminthics: Enantioselective sulphoreduction in sheep and cattle. J. Vet. Pharmacol. Ther. 25, 1:15-23.

Wilson, NO, Hall, RL, Montgomery, SP, Jones, JL, 2015: Trichinellosis surveillance-United States, 2008- 2012. MMWR. Surveill Summ, 16, 64, 1:1-8.

Xia, Y, Fan, Q, Hao, D, Wu, J, Ma, G, et al, 2015: Chitosan-based mucosal adjuvants: Sunrise on the ocean. Vaccine 33: 5997-6010.

Yu, YR, Deng, MJ, Lu, WW, Jia, MZ, Wu, W, et al, 2013: Systemic cytokine profiles and splenic toll-like receptor expression during Trichinella spiralis infection. Exp. Parasitol. 134, 1:92-101.

Yu, YR, Qi, YF, 2015: Progress in treatment and prevention of trichinellosis. J. Infect. Dis. Ther. 3: 251-6.

Yu, Z, Zhao, L, Ke, H, 2004: Potential role of nuclear factor-kappa $\mathrm{B}$ in the induction of nitric oxide and tumor necrosis factor-alpha by oligochitosan in macrophages. Int. Immunopharmacol, 4, 2:193-200.

Zeromski, J, Boczoń, K, Wandurska-Nowak, E, Mozer-Lisewska, I, 2005: Effect of aminoguanidine and albendazole on inducible nitric oxide synthase (iNOS) activity in T. spiralis-infected mice muscles. Folia Histochem. Cytobiol 43, 3:157-9.

\section{Explanation of figures}

Fig. 1a: TS in intestine of GV (TTT by $\mathrm{CH}+$ full ABZ) showed very mild inflammation with scarce inflammatory infiltrate in lamina propria (green arrow) mainly lymphocytes with intact mucosa, intestinal villi and crypts (yellow arrows) and muscularis mucosa in addition to mild edema (H\&E, x100).

Fig. 1b: TS in intestine of GIII (TTT by ABZ) showed mild to moderate inflammation, dense inflammatory infiltrate in lamina propria mainly lymphocytes and mast cells, plasma cells, edema (yellow arrow) and intact cylindrical intestinal villi (red arrow) (H\&E, x100). Fig. 1c: TS in intestine of GIV (TTT by $\mathrm{CH}$ ) showed severe inflammation with dense inflammatory infiltrate in lamina propria (green arrows) mainly lymphocytes, plasma cells and eosinophil's (E) in addition to moderate edema and ulceration (yellow arrows) (H\&E) (x100).

Figu.1d: TS in intestine of GV (TTT by CH + full ABZ) showed diffuse mild iNOS expression in lining epithelial cells, cytoplasm, inflammatory cells in lamina propria, and in muscularis mucosa (green arrows) (x200).

Fig. 1e: TS in intestine of GIII (TTT by ABZ) showed diffuse moderate iNOS expression in lining epithelial cells, cytoplasm, inflammatory cells in lamina propria (green arrows) and negative expression in muscularis mucosa (red arrow) (x200).

Fig. 1f: TS in intestine of GIV (TTT by $\mathrm{CH}$ ) showed diffuse moderate iNOS expression in lining epithelial cells, strong expression in cytoplasm, inflammatory cells in lamina propria and in muscularis mucosa (green arrows) (x200). 
Fig. 1g: SEM of $T$. spiralis adult of an infected control mouse showing primary folds with large spacing. Transverse creases (C) and hypodermal glands opening $(\mathrm{G})$.

Fig. 1h: SEM of T. spiralis adult of an infected treated with $\mathrm{CH}+$ full $\mathrm{ABZ}$ showed sloughing of wall with complete large opening $(\mathrm{O})$ due to rupture of cuticle with complete disappearance of internal content and multiple fissures with loss of normal annulations of cuticle (green arrows).

Fig. 1i: SEM of T. spiralis adult of an infected treated with $\mathrm{CH}$ showed sloughing and erosion of some areas of cuticle and large blebs (yellow arrow) with fissure and loss of normal annulations of cuticle (green arrow).
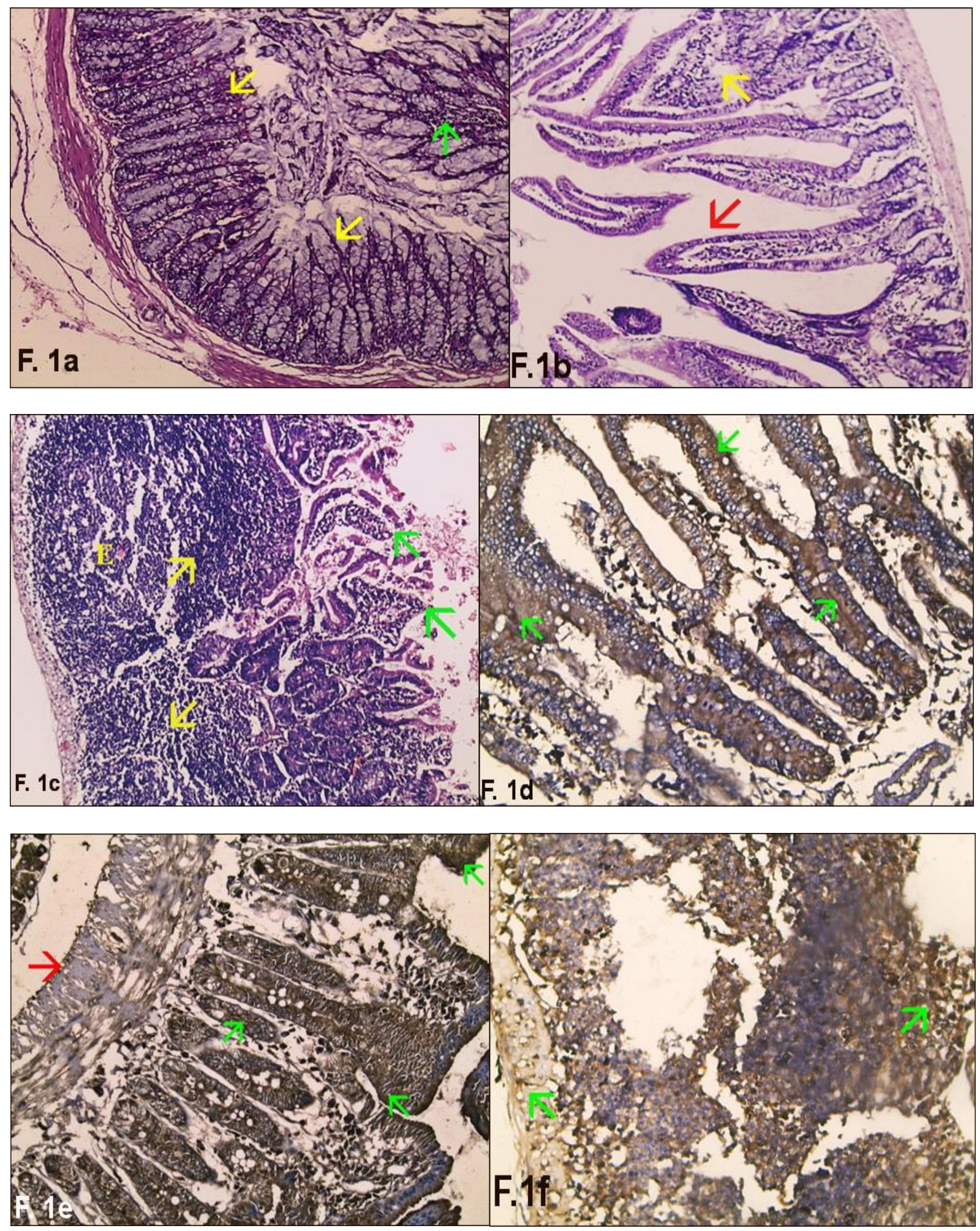

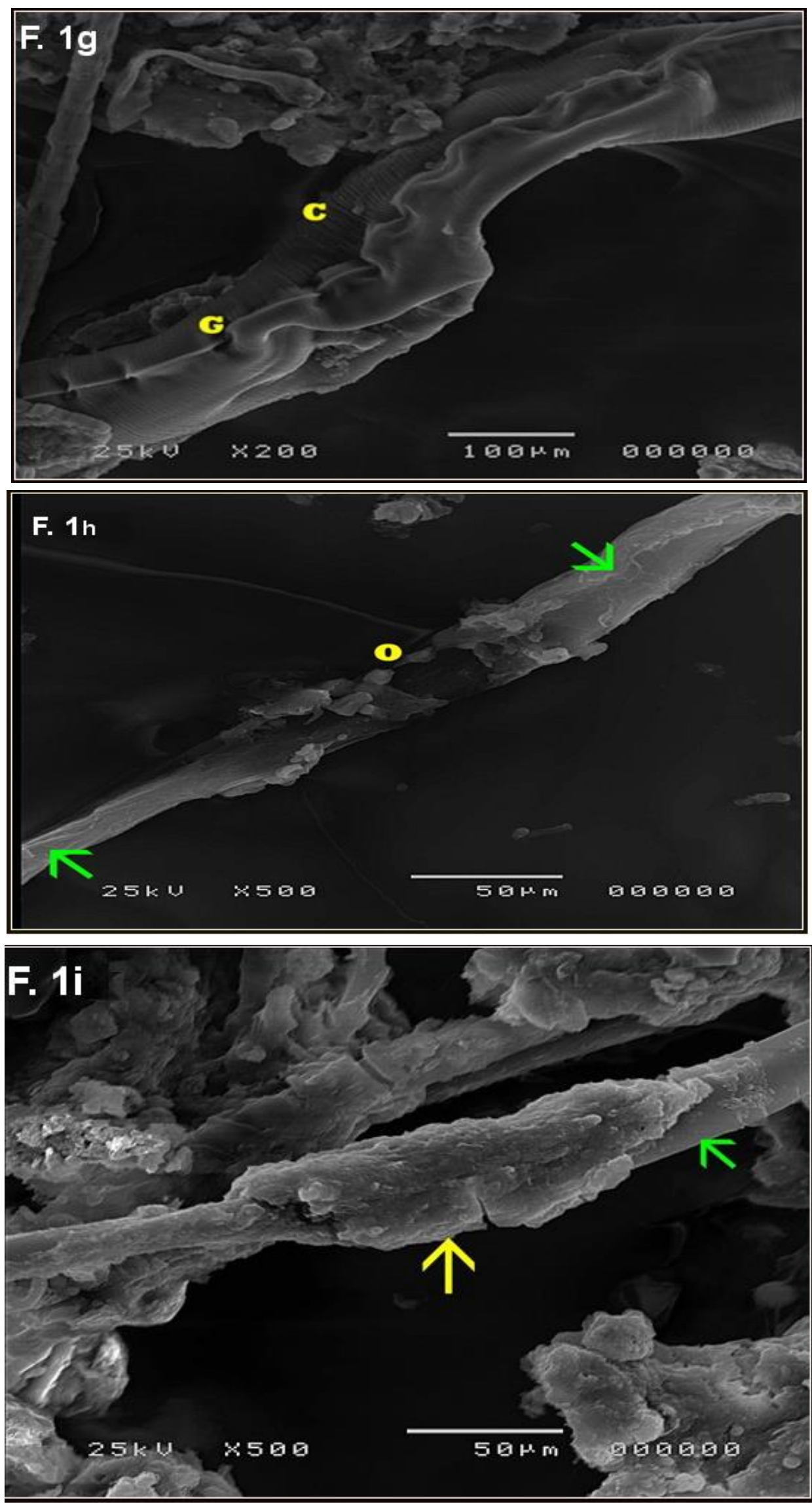